\title{
Analysis of Retrofitted Cold Formed Steel Multistory Building Frame
}

\author{
Udayakumar, Aravind Kumar B. Harwalkar
}

\begin{abstract}
The cold formed steel section are increasingly used as a structural elements in low rise buildings in recent times, due to the advantages like economic production, easy transportation, low labor cost and high strength to weight ratio. In the current work a G+3 storied building frame is studied for seismic and wind load using Staad-pro software. Light gauge section is taken for beam and slab elements. The seismic analysis is carried out by Equivalent static method. After analysis the results such as story displacement, story drift, Base shear and time period are compared for different models. The building frame is also analyzed for wind load. In the current work cross bracing using Light gauge element used as a retrofitting technique. The retrofitted building frame is analyzed for wind and seismic loads and results obtained for time period, storey displacement, storey drift and base shear values are compared with the corresponding values of base frame. The results of retrofitted frame showed shortening in time period, storey displacement and story drift values in $X \& Z$ directions indicating the increased ductility, Stiffness and strength of structure. Hence the proposed retrofitting technique could be believed to achieve success results in increased strength and ductility values required by wind and seismic loading.
\end{abstract} Drift, Base Shear, Time Period, Retrofitting.

\section{INTRODUCTION}

Steel as a structural material has become the perfect choice in the construction sector for its innumerable advantages over other building materials. Steel used in the construction mainly categorized into two families as hot rolled shapes member and plates and other is cold form steel. Although first one is the most familiar, various benefits of cold formed steel are growing interest in both the research and construction sectors especially in Industrialized Countries, like USA, Canada, Australia and some European Countries. In the construction of low-rise residential building, transmission towers and commercial building cold-formed steel is being used as a structural element. It is also being used in the construction of bridge, storage and drainage facilities, bins etc. Recently the application of cold formed steel has increased in buildings for its inherent features like higher weight to strength ratio, adaptability, non- combustibility, and easier production process.

Manuscript received on August 31, 2021.

Revised Manuscript received on September 05, 2021.

Manuscript published on September 30, 2021.

Udayakumar, PG Student, Department of Civil Engineering, PDA College of Engineering Kalaburgi-585102, Karnataka, India E-mail: udayakumarpatil123@gmail.com

Dr. Aravind Kumar B Harwalkar, Associate Professor Department of Civil Engineering, PDA College of Engineering Kalaburgi-585102, Karnataka, India. E-mail: harwalkar_ab@yahoo.co.in

(C) The Authors. Published by Blue Eyes Intelligence Engineering and Sciences Publication (BEIESP). This is an open access article under the CC BY-NC-ND license (http://creativecommons.org/licenses/by-nc-nd/4.0/)
Keywords: Cold Formed Steel, Storey Displacement, Storey

The architects are encouraged by these advantageous properties of cold formed steel structures and aesthetic appeal. Due to good structural performance and economy, it is also a good choice for engineers, contractors, and owners.

\section{A. Retrofitting of cold formed steel structures:}

The retrofitting technique using CFS section transforms the open-channel Hot rolled steel (HRS) section to a closed composite (HRS-CFS) section, thereby increasing its torsion rigidity to inhibit failure due to lateral-torsion buckling (LTB). The integrity of the HRS-CFS section was ensured by adequate spot welding of the CFS section to the HRS at regular intervals along the length of the member. This technique has the advantage of accumulating minimum residual stress (spot welding) in addition to reduced manpower required for section fabrication. The test results, in general, indicate that this technique can significantly increase the load-carrying capacity (up to 60\% compared to the control specimen) without deformation when local buckling of the CFS sections can be prevented by providing adequate thickness and smaller weld intervals. The retrofit process is a general term that may consist of a variety of treatments, including: preservation, rehabilitation, restoration and reconstruction. Selecting the appropriate treatment strategy is a great challenge involved in the retrofit process and must be determined individually for each project. Depending on project objectives, preservation and renovation of buildings may involve an array of diverse technical considerations, such as fire life safety, geotechnical hazards and remedies, weathering and water infiltration, structural performance under earthquake and wind loads.

In the current project work it is aimed to study the behavior of retrofitted building frame with light gauge section under seismic and wind loading.

\section{LITERATURE REVIEW}

Giuseppe OlivetoAnd Massimo Marletta[1] considered the retrofitting of buildings vulnerable to earthquakes and briefly described the main traditional and innovative methods of seismic retrofitting. Among all the methods of seismic retrofitting, particular attention was devoted to the method which was based on stiffness reduction. This method was carried out in practice by application of the concept of springs in series, which lead in fact to base isolation. One of the two springs in series represented the structure and the other represented the base isolation system. The enhanced resistance of the buildings to the design earthquake clearly showed the effectiveness of the method, while a generally improved seismic performance also emerged from the application.

\section{Published By:}

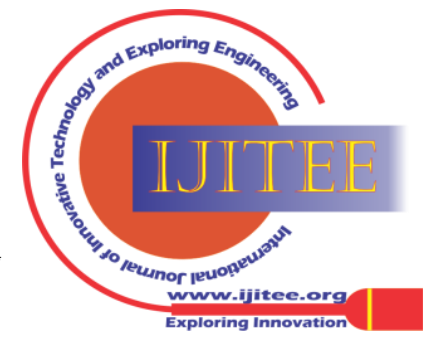




\section{Analysis of Retrofitted Cold Formed Steel Multistory Building Frame}

A general study of Light Gauge Steel Structures - A Review was undertaken by S. Vignesh Kannan et al [2]. Cold-Formed Steel (CFS) sections are widely employed in the construction of industrial building components all over the world. More advantages in Hot Rolled Steel (HRS) Sections have been achieved as a result of the adoption of CFS. The current study looks at how different CFS sections can be used to achieve specific goals such as good fire resistance, low local buckling, high flexural strength, acceptable seismic response, and bracing performance. The CFS hollow sections, in particular, have significant loading rates, and the use of infill material (geopolymer concrete) produces the greatest results in building element joints. The numerous characters are described for use in various construction parts such as main walls, shear wall panels, tension members, compression members, and roof elements, among others. Finally, CFS sections that perform well in finite element analysis were investigated.

Ravindra B. Kulkarni et al [3] studied on "Experimental investigation on cold formed light gauge rectangular hollow section with welded knee joints" The most of the structural steel members used in structures has to span great length and surround a large three-dimensional space. The lengths of the members are required to increase by suitable connection (By Bolted/ Welded). Thus, connections are needed to form an important steel structural member. Very less work is done in welded connections in Cold formed Light sections. The present study is motivated on determining the experimental tests on welded Connections for Light gauge cold formed Rectangular hollow sections. In this project, there are seven experiments conducted on $60 \mathrm{mmx} 40 \mathrm{mmx} 1.6 \mathrm{~mm}$ Rectangular hollow Sections. The experimental tests included flexural tests on full welded sections with various types beam column joint connections and the results were compared to codal values. It is found that, the knee plate welded connection with full all-round with knee plate leg size of $S=1.5 d$ has given high strength. Hence there is increase of load with increase of leg size of knee plate. This type of connection has got higher moment capacity.

Weiming Yan et al [4] published a report that compared the mechanical behaviour and construction characteristics of certain common cold-formed thin-walled steel connectors. A total of 96 specimens were subjected to lap shear tests that included a self-piercing rivet, clinching, self-drilling screw, and blind rivet. The effects of sheet thickness and thickness ratio on failure modes and mechanical behaviour of the four types of connections were investigated. Through analyzing the feasibility of mechanic and construction, the applicability of the four types of connections in fabricated cold-formed steel structures was comprehensively evaluated. The result of the research shows that compared with the other three connections; self-piercing rivet connections are more suitable for modularly fabricated cold-formed steel structures.

\section{OBJECTIVES}

The main aim of the project work is as follows

1. Analysing steel frame with cold form steel section for $\mathrm{G}+3$ storied building for wind and seismic loading.

2. To study the different parameters like lateral storey displacement, base shear, time period and storey drift.
3. Analysing the Retrofitted steel frame with cold form steel section for wind and seismic loading.

\section{SCOPE OF THE STUDY}

1. To ensure the safety and security of CFS buildings, employees, structure functionality, machinery and inventory.

2. It is essential to reduce hazard and loses from CFS structural element

3. Important buildings must be strengthened whose services are assumed to be essential just after an earthquake like hospitals.

\section{METHODOLOGY}

The proposed Cold Formed Steel Structure is analysed and designed by STAAD Pro v8i SS6. Following are the steps to create proposed model and analyze.

\section{Inputs:}

Model creation

(Nodes, Beams, Secondary Beams and Columns)

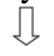

Defining the material properties of the structure \

Defining Supports<smiles>C1=CC=C1</smiles>

Defining loads, Assigning the loads and its combinations on the structure

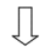

Analysis and print<smiles>[CH]=[CH]</smiles>

Run analysis<smiles>C1=CC=C1</smiles>

outputs

П

(time period, storey displacement, storey drift and base shear)

\section{ANALYTICAL MODELLING}

\section{General description of the model}

1. In present study an attempt is made to investigate the seismic effect on cold formed steel framed building.

2. The analysis of G+3 CFS framed building is carried out using Staad-Pro software

3. Analysis is carried out for seismic Zone-III.

4. The type of soil taken for analysis is type-II medium soil.

5. After analyzing different models in Staad-pro software the parameters like Storey displacement, Base shear, Storey drift, and time period.

6. Finally the result obtained for different models are compared.

\section{A. Description of the models:}

Total Sixteen Models were prepared out of which 8 models for seismic analysis and 8 models for wind analysis.

\section{Model 1 to 8 seismic analysis}

\section{Published By:} aciences Publication (C) Copyright: All rights reserved.

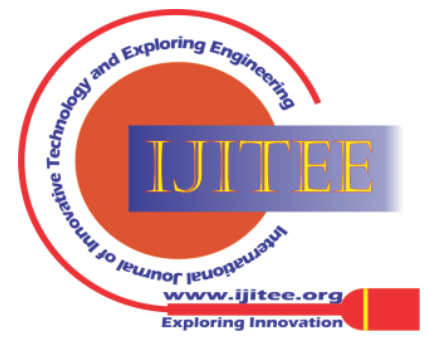


Model 1: Standard model G+3 storey, in this model columns are hot rolled and beams are channel with lips.

Model 2: Standard model G+3 storey, in this model columns are hot rolled and beams are channel with lips, retrofitted with bracing along $\mathrm{X}$-direction.

Model 3: Standard model G+3 storey, in this model columns are hot rolled and beams are channel with lips, retrofitted with bracing along Z-direction.

Model 4: Standard model G+3 storey, in this model columns are hot rolled and beams are channel with lips, retrofitted with bracing along $\mathrm{X}$ and $\mathrm{Z}$-direction.

Model 5: Standard model G+3 storey, in this model columns are hot rolled and beams are Zee with lips.

Model 6: Standard model G+3 storey, in this model columns are hot rolled and beams are Zee with lips, retrofitted with bracing along X-direction.

Model 7: Standard model G+3 storey, in this model columns are hot rolled and beams are Zee with lips, retrofitted with bracing along Z-direction.

Model 8: Standard model G+3 storey, in this model columns are hot rolled and beams are Zee with lips, retrofitted with bracing along $\mathrm{X}$ and $\mathrm{Z}$-direction.

Above same models are also analysed wind load.

Modelling different types of model using staad pro:

Model1- Standard model G+3 storey, in this model columns are hot rolled and beams are channel with lips and is shown in Fig 4.1.and Fig 4.2 shows typical light gauge section used for beams

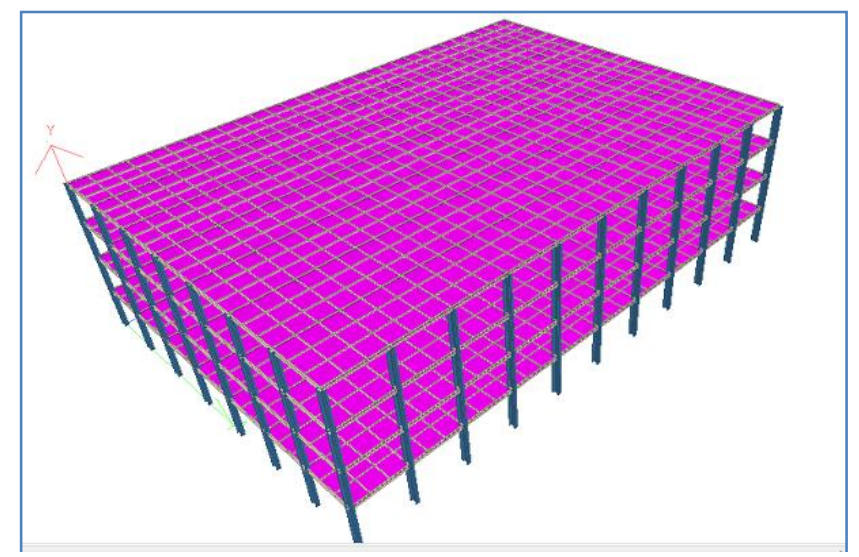

Fig 4.1: 3D Model of Structure

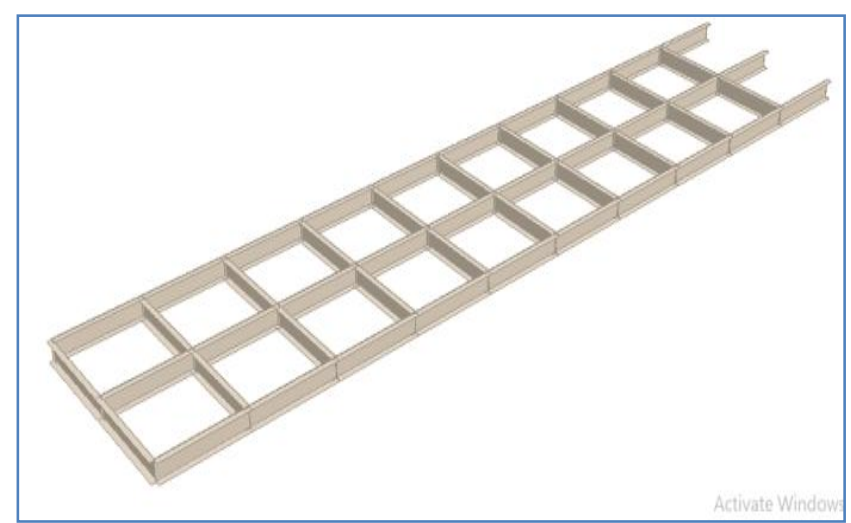

Section Channel with lip

Model 2: Standard model G+3 storey, in this model columns are hot rolled and beams are channel with lips, retrofitted with bracing along X-direction and is shown in Fig 4.3.

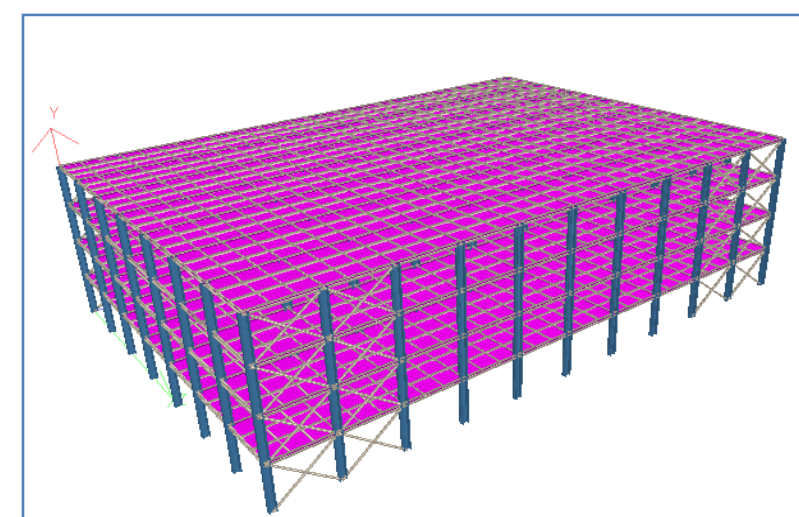

Fig 4.3: 3D Model of Structure with bracing along X-Direction

Model 3: Standard model G+3 storey, in this model columns are hot rolled and beams are channel with lips, retrofitted with bracing along Z-direction and Fig 4.4 shows model 3.

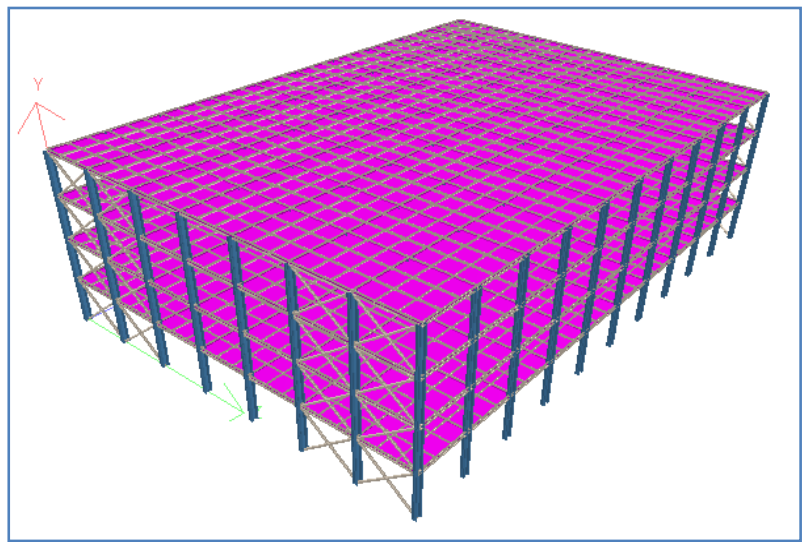

Fig 4.4: 3D Model of Structure with bracing along Z-Direction

Model 4: Standard model G+3 storey, in this model columns are hot rolled and beams are channel with lips, retrofitted with bracing along $\mathrm{X}$ and Z-direction and is shown in Fig 4.5.

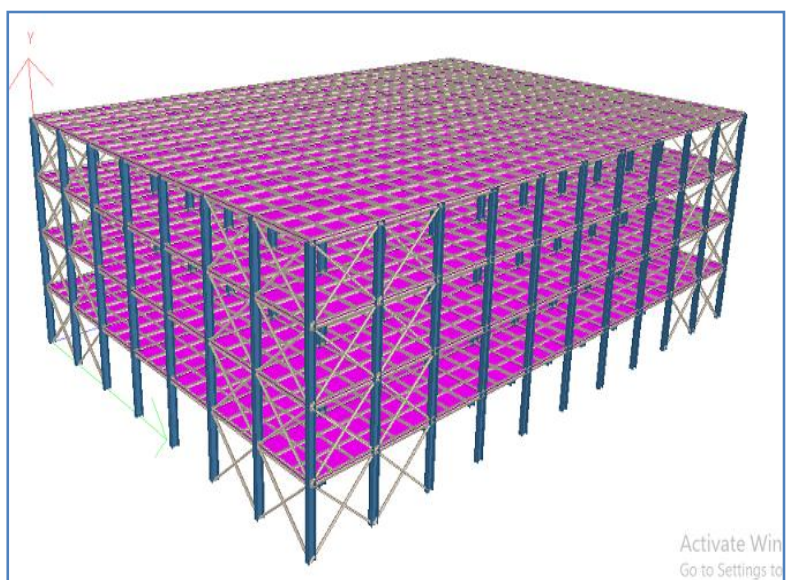

Fig 4.5: 3D Model of Structure with bracing along $X$ and $\mathrm{Z}$-Direction

Model 5: Standard model G+3 storey, in this model columns are hot rolled and beams are Zee with lips and shown in Fig 4.6. and Fig 4.7 shows beam section of zee with lip.

Blue Eyes Intelligence Engineering and Sciences Publication

(C) Copyright: All rights reserved.

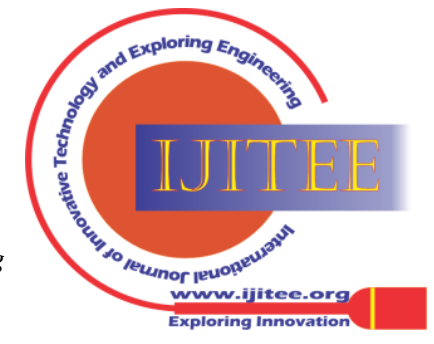




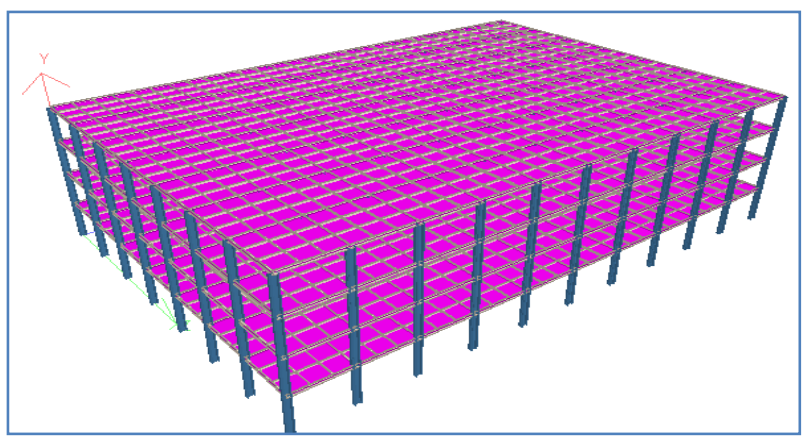

Fig 4.6: 3D Model of Structure and beams are Zee with lip

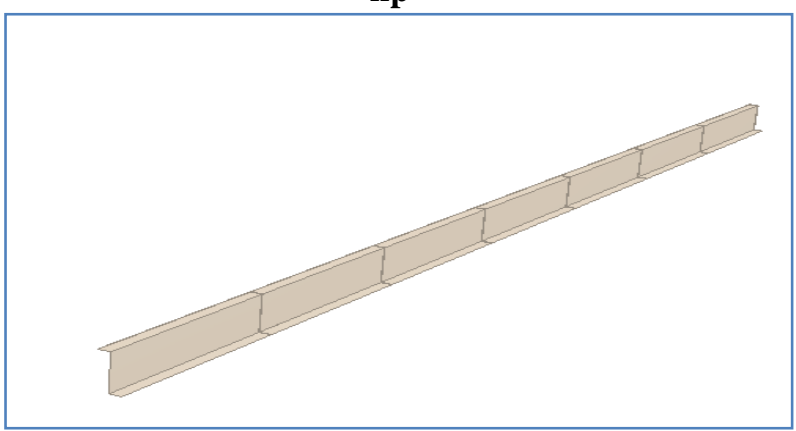

Section Zee with lip

Model 6: Standard model G+3 storey, in this model columns are hot rolled and beams are Zee with lips, retrofitted with bracing along $\mathrm{X}$-direction and is shown in Fig 4.8 .

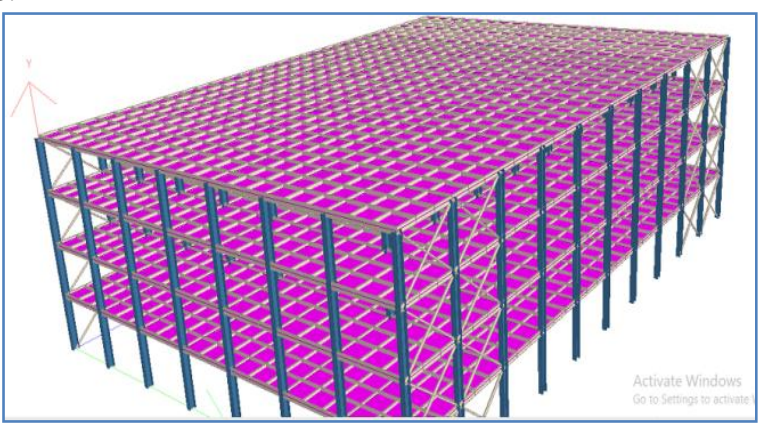

Fig 4.8: 3D Model of Structure and beams of Zee with lip with bracing along $X$-Direction

Model 7: Standard model G+3 storey, in this model columns are hot rolled and beams are Zee with lips, retrofitted with bracing along Z-direction and is shown in Fig 4.9.

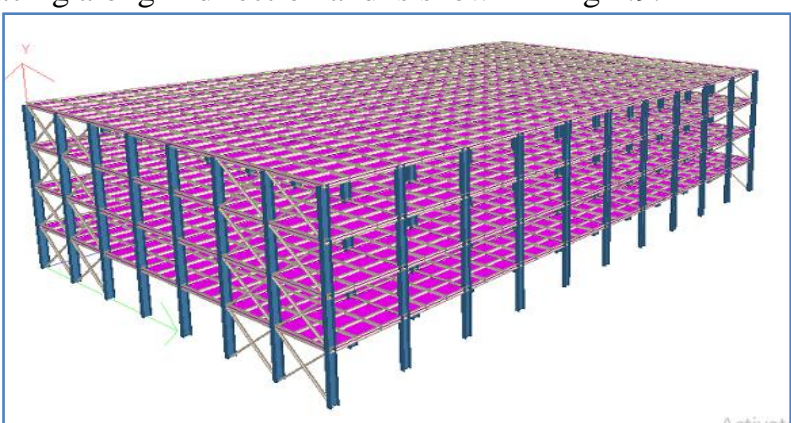

Fig 4.9: 3D Model of Structure and beams of Zee with lip with bracing along Z-Direction

Model 8: Standard model G+3 storey, in this model columns are hot rolled and beams are Zee with lips, retrofitted with bracing along $\mathrm{X}$ and Z-direction. and is shown in Fig 4.10.
Published By:

Blue Eyes Intelligence Engineering and Sciences Publication

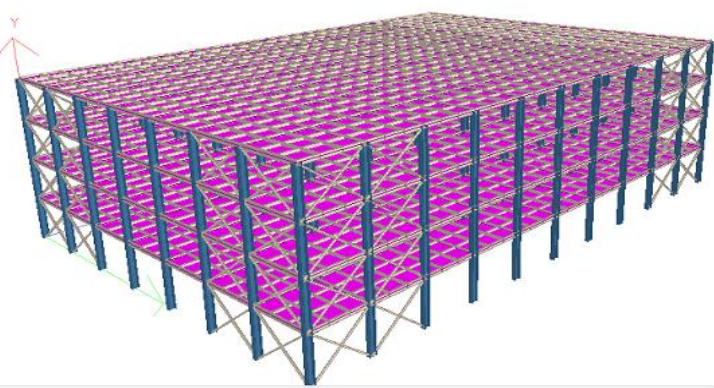

Fig 4.10: 3D Model of Structure and beams of Zee with lip with bracing along $X$ and $Z$-Direction.

Table I. Details of the Structure

\begin{tabular}{|c|c|}
\hline Type of Building & Residential Building \\
\hline Type of frame & Steel moment resisting frame \\
\hline No of stories & $\mathrm{G}+3$ \\
\hline $\begin{array}{l}\text { Total height of } \\
\text { building }\end{array}$ & $12.20 \mathrm{~m}$ \\
\hline Length of building & $40 \mathrm{~m}$ \\
\hline Width of building & $28 \mathrm{~m}$ \\
\hline Thickness of wall & $100 \mathrm{~mm}$ \\
\hline Live load & 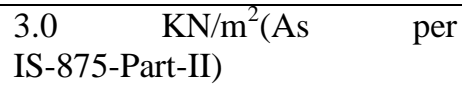 \\
\hline Grade of concrete & M20 \\
\hline $\begin{array}{l}\text { Density of } \text { Brick } \\
\text { masonry }\end{array}$ & $20 \mathrm{KN} / \mathrm{m}^{3}$ \\
\hline Size of column & ISHB 400 \\
\hline Size of Beam & $\begin{array}{l}\text { 250CS80x5 for channel with lip } \\
\text { 300ZS75x3.15 for Zee with lip }\end{array}$ \\
\hline Bracing & Angle 100LU100x6 \\
\hline Thickness of sheet & $0.65 \mathrm{~mm}$ \\
\hline Thickness of slab & $75 \mathrm{~mm}$ \\
\hline Seismic Zone & III \\
\hline Wind & $44 \mathrm{~m} / \mathrm{s}$ \\
\hline Type of soil & medium \\
\hline Importance factor & 1.5 \\
\hline Damping ratio & $5 \%$ \\
\hline
\end{tabular}

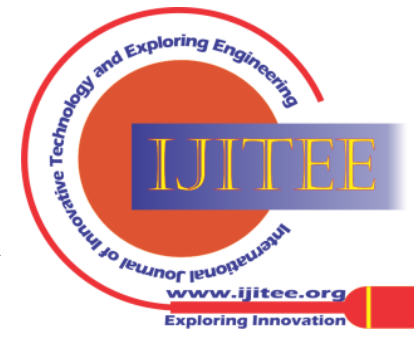




\section{A. Loads:}

1. Dead load as per IS 875(part I)- 1987

2. Live load as per IS 875(part II)- 1987

3. Wind load as per IS 875(part III)- 1987

4. Earthquake load as per IS 1893(part I)- 2002

The Seismic Analysis Methods can be listed as follows

1) Equivalent Static Analysis (Linear Static)

2) Response Spectrum Analysis (Linear Dynamic)

3) Pushover Analysis (Nonlinear Static)

4) Time History Analysis (Nonlinear Dynamic)

In the current project work design lateral force due to earthquake is determined by equivalent static method. Which is also known as seismic coefficient method or linear static method. This method is initiated to be simple method as it involves less computational effort and is centred on the formulae as per the code of practice. First the design base shear is computed for the whole given platform and then the resulted base shear is distributed all along the height of the deck platform.

\section{RESULT AND DISCUSSION}

\section{A. seismic load analysis}

Time period: It is defined as time required completing one cycle of vibration to pass in a given point and graphically represented in Fig 5.1.

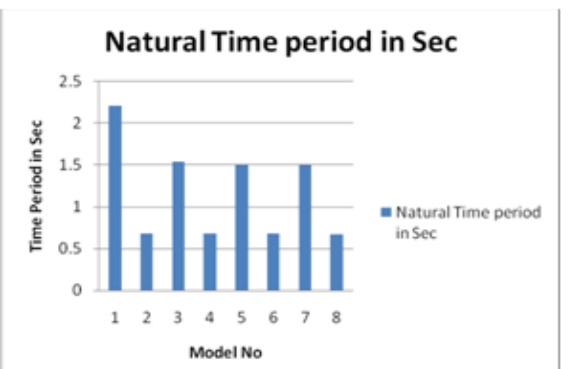

Fig 5.1 Time period for all models

From the chart it is observed that the time period for model 1 is maximum. When we introduce bracing in X-direction in model 2 the time period is decreases by $69.30 \%$ compare to model 1, whereas for model 3 with bracing in Z-direction the time period is decreases by $30.15 \%$ compare to model1, whereas for model 4 with bracing in $\mathrm{X}$ and Z-direction the time period is decreases by $69.44 \%$ compare to model1,

Storey displacement: It is defined as total displacement of $\mathrm{i}^{\text {th }}$ storey with respect to ground. and graphically represented in Fig 5.2. Fig 5.3. Fig 5.4\& Fig 5.5.

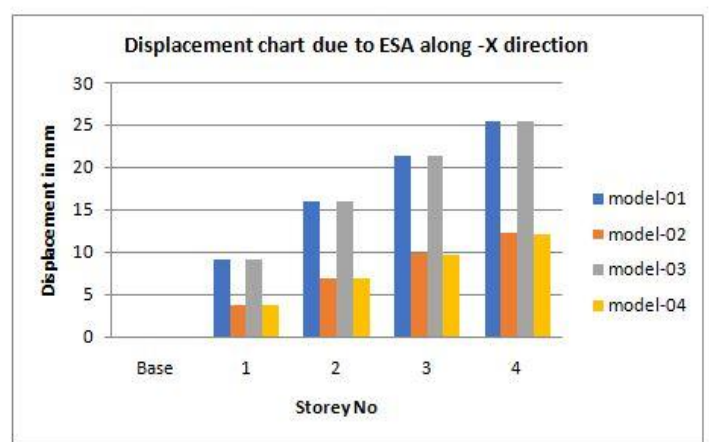

Fig 5.2: Storey displacement in $\mathrm{mm}$ for various models along $\mathrm{X}$-direction due to ESA, all models are Channel with lip.
From the Fig 5.2 it is observed that the storey displacement is maximum for model 1 along X-direction. When we add bracing in X-direction the storey displacement is decreases by $52.32 \%$ in model 2 , when we add bracing in Z-direction the storey displacement is decreases by $0.117 \%$ in model 3 , when we add bracing in $\mathrm{X}$ and $\mathrm{Z}$ direction the storey displacement is decreases by $52.36 \%$ in model 4 compared to model 1.

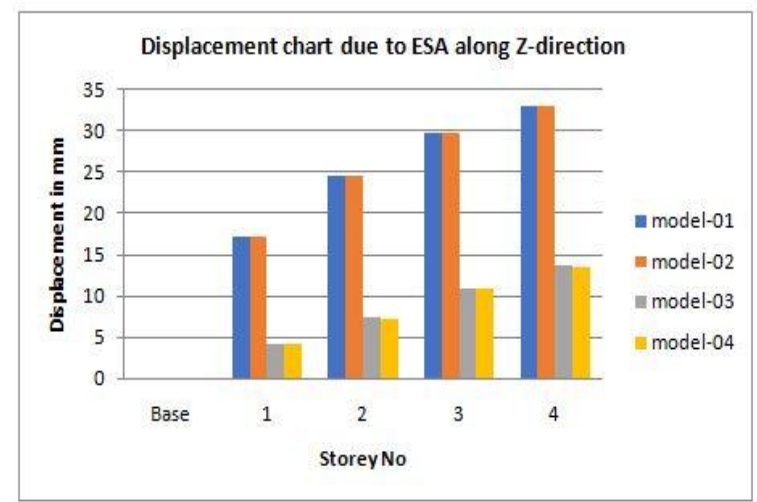

Fig 5.3: Storey displacement in $\mathrm{mm}$ for various models along Z-direction due to ESA, all models are Channel with lip.

From the Fig 5.3 it is observed that the storey displacement is maximum for model 1 along Z-direction. When we add bracing in X-direction the storey displacement remain same in model 2, when we add bracing in Z-direction the storey displacement is decreases by $58.49 \%$ in model 3 , when we add bracing in $\mathrm{X}$ and $\mathrm{Z}$ direction the storey displacement is decreases by $58.89 \%$ in model 4 compared to model

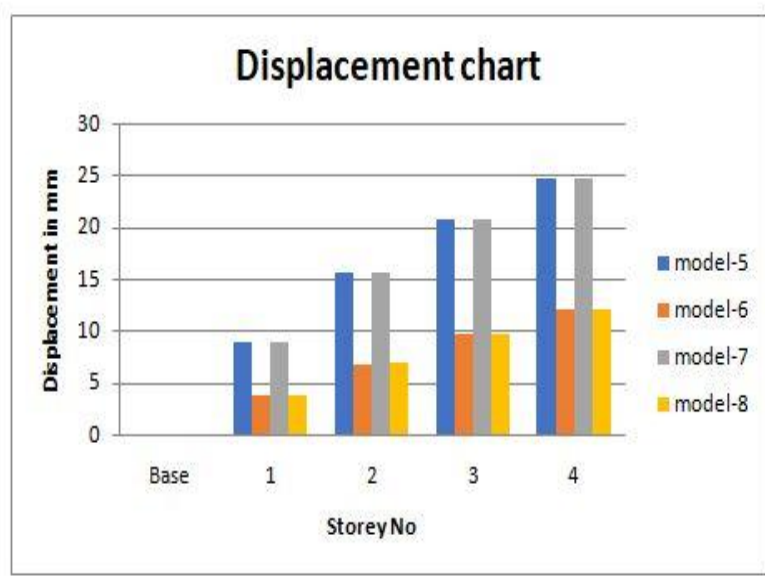

Fig 5.4: Storey displacement in $\mathrm{mm}$ for various models along $\mathrm{X}$-direction due to ESA, all models are ZEE with lip

From the Fig 5.4 it is observed that the storey displacement is maximum for model 5 along X-direction. When we add bracing in X-direction the storey displacement is decreases by $51.39 \%$ in model 6 , when we add bracing in Z-direction the storey displacement is decreases by $0.08 \%$ in model 7 , when we add bracing in $\mathrm{X}$ and $\mathrm{Z}$ direction the storey displacement is decreases by $50.91 \%$ in model 8 compared to model 1.

\section{Published By:}

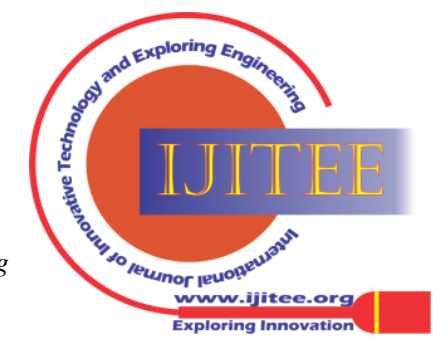




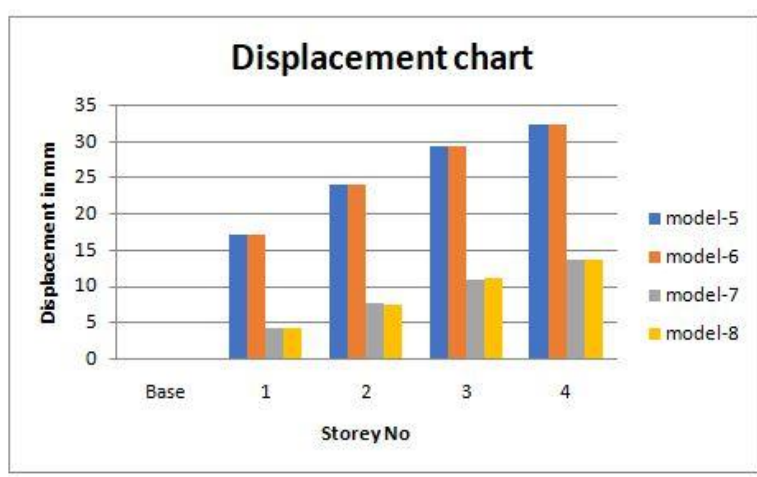

Fig 5.5: Storey displacement in mm for various models along Z-direction due to ESA, all models are ZEE with lip From the Fig 5.5 it is observed that the storey displacement is maximum for model 5 along Z-direction. When we add bracing in X-direction the storey displacement is slightly increases by $0.154 \%$ in model 6 , when we add bracing in Z-direction the storey displacement is decreases by $57.78 \%$ in model 7, when we add bracing in $\mathrm{X}$ and $\mathrm{Z}$ direction the storey displacement is decreases by $57.85 \%$ in model 8 compared to model 1.

Storey drift: It is defined as the ratio of displacement of two consecutive floors to height of that floor. Storey drift values are graphically represented in Fig 5.6, Fig 5.7. Fig 5.8 and Fig 5.9 .

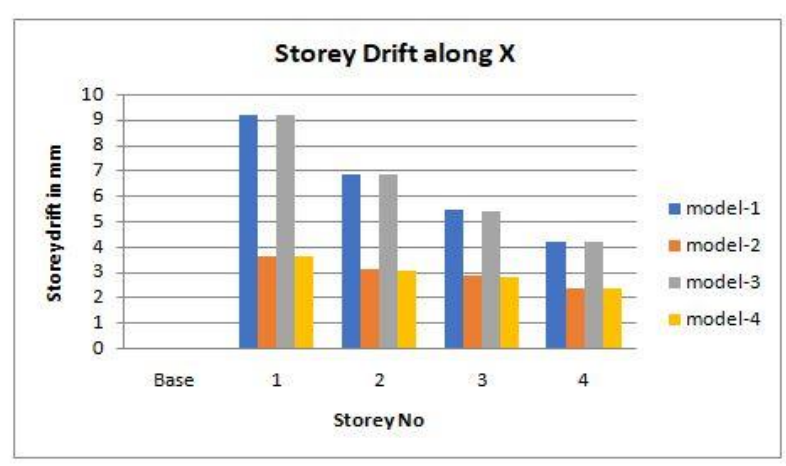

Fig 5.6: Storey drift in $\mathrm{mm}$ for various models along $\mathrm{X}$-direction due to ESA, all models are Channel with lip

From the Fig 5.6 it is observed that the storey drift is maximum for model 1 along X-direction. When we add bracing in X-direction the storey drift is decreases by $44.09 \%$ in model 2, when we add bracing in Z-direction the storey drift remains same in model 3, when we add bracing in $X$ and $\mathrm{Z}$ direction the storey drift is decreases by $44.09 \%$ in model 4 compared to model 1.

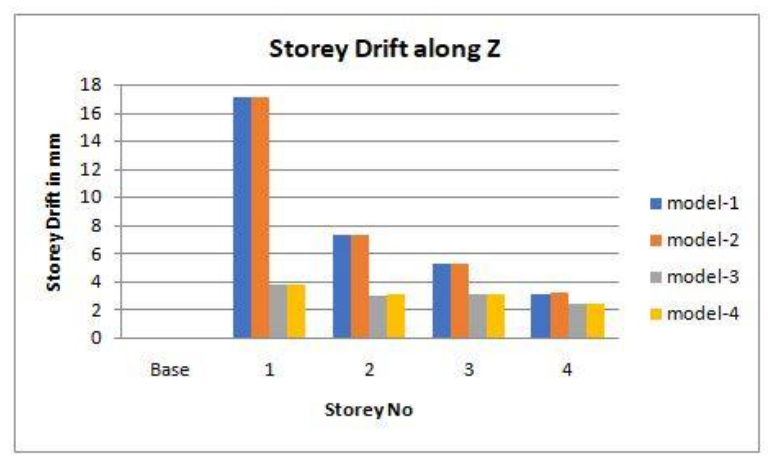

Fig 5.7: Storey drift in $\mathrm{mm}$ for various models along Z-direction due to ESA, all models are Channel with lip

From the Fig 5.7 it is observed that the storey drift is maximum for model 1 along Z-direction. When we add bracing in $\mathrm{X}$-direction the storey drift remains same in model when we add bracing in Z-direction the storey drift by $22.81 \%$ in model 3 , when we add bracing in $X$ model 4 compared to model 1 .

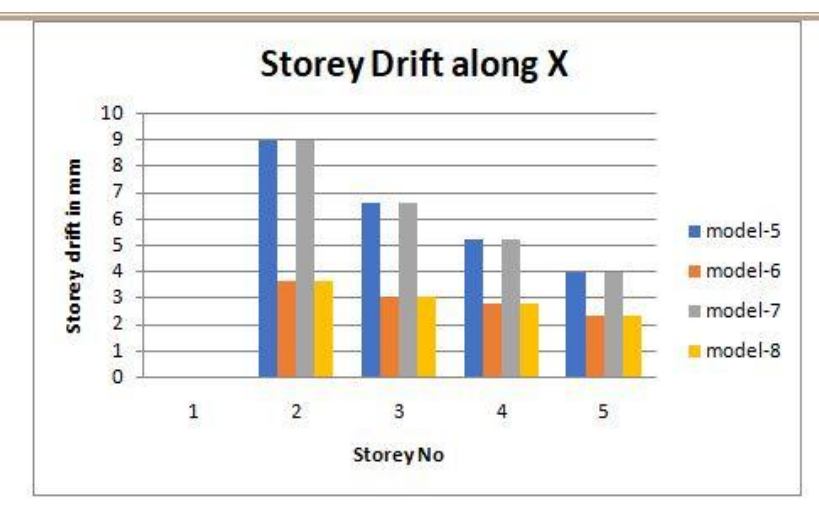

Fig 5.8: Storey drift in $\mathrm{mm}$ for various models along $\mathrm{X}$-direction due to ESA, all models are Zee with lip

From the Fig 5.8 it is observed that the storey drift is maximum for model 5 along X-direction. When we add bracing in X-direction the storey drift is decreases by $41.73 \%$ in model 6, when we add bracing in Z-direction the storey drift remains same in model 7 , when we add bracing in $X$ and $\mathrm{Z}$ direction the storey drift is decreases by $41.73 \%$ in model 8 compared to model 5.

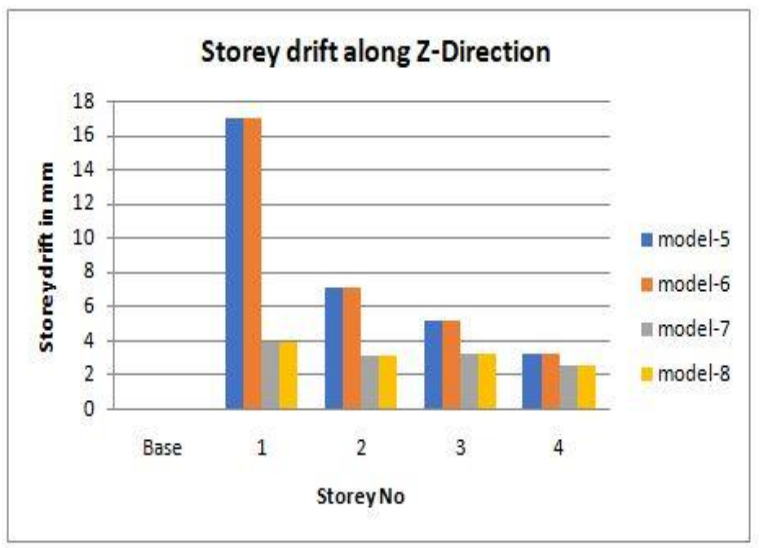

Fig 5.9: Storey drift in $\mathrm{mm}$ for various models along Z-direction due to ESA, all models are Zee with lip

From the Fig 5.9 it is observed that the storey drift is maximum for model 5 along Z-direction. When we add bracing in X-direction the storey drift is decreases by $0.313 \%$ in model 6, when we add bracing in Z-direction the storey drift decreases by $22.88 \%$ in model 7 , when we add bracing in $\mathrm{X}$ and $\mathrm{Z}$ direction the storey drift is decreases by $22.88 \%$ in model 8 compared to model 5.

Base shear: It is an estimate of the maximum expected lateral forces that will occur due to seismic ground motion at the base of a structure.

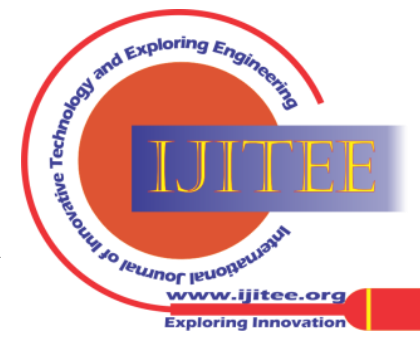


Base shear values for various models are graphically represented in Fig 5.10.

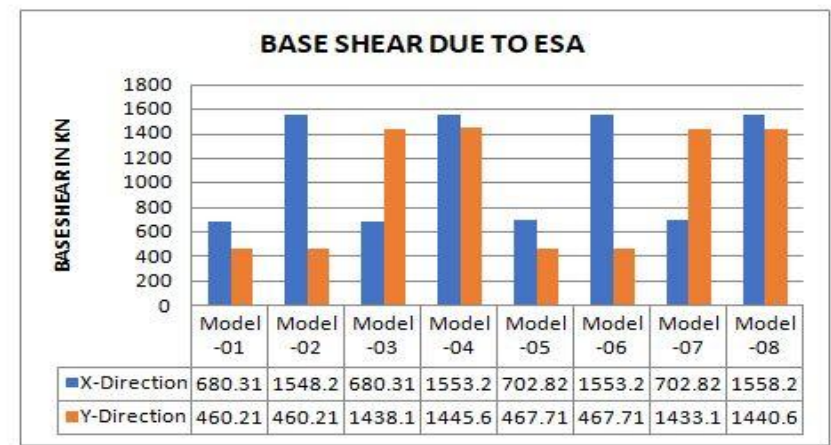

Fig 5.10: Base shear in $\mathrm{KN}$ for various models along $\mathrm{X}$ and Z-direction due to ESA, for all models.

From the Fig 5.10 it is observed that the base shear is minimum for model 1 along X-Direction and when we add bracing in $\mathrm{X}$-direction the base shear gets increases by $56.05 \%$ for model 2, when we add bracing in Z-direction the base shear remains same in model 3 , when we add bracing in X \& Z direction the base shear gets increases by $56.19 \%$ in model 4 compared to model 1 .

From the Fig 5.10 it is observed that the base shear is minimum for model 1 along Z-Direction and when we add bracing in $\mathrm{X}$-direction the base shear remains same, for model 2, when we add bracing in Z-direction the base shear increase by $68 \%$ in model 3 , when we add bracing in $\mathrm{X} \mathrm{\&} \mathrm{Z}$ direction the base shear gets increases by $68.16 \%$ in model 4 compared to model 1. From the Fig 5.10 it is observed that the base shear is minimum for model 5 along $\mathrm{X}$-Direction and when we add bracing in $\mathrm{X}$-direction the base shear gets increases by $54.75 \%$ for model 6 , when we add bracing in Z-direction the base shear remains same in model 7, when we add bracing in $\mathrm{X} \& \mathrm{Z}$ direction the base shear gets increases by $54.89 \%$ in model 8 compared to model 5 .

From the Fig 5.10 it is observed that the base shear is minimum for model 5 along Z-Direction and when we add bracing in $\mathrm{X}$-direction the base shear remains same, for model 6, when we add bracing in Z-direction the base shear increases by $67.36 \%$ in model 7 , when we add bracing in $X$ \& $\mathrm{Z}$ direction the base shear gets increases by $67.53 \%$ in model 8 compared to model 5 .

\section{B. wind load analysis:}

Storey displacement: Storey displacement values are graphically represented in Fig 5.11., Fig 5.12. Fig 5.13.and Fig 5.12.

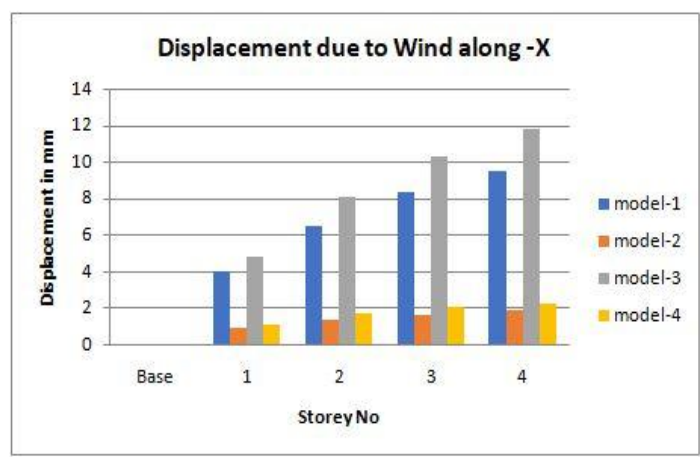

Fig 5.11: Storey displacement in $\mathrm{mm}$ for various models along $\mathrm{X}$-direction due to Wind, all models are Channel with lip.

From the Fig 5.11 it is observed that the storey displacement for model 1 is $9.49 \mathrm{~mm}$ along X-direction. When we add bracing in $\mathrm{X}$-direction the storey displacement is decreases by $80.82 \%$ in model 2, when we add bracing in Z-direction when we add bracing in $X$ and $Z$ direction the storey model 1.

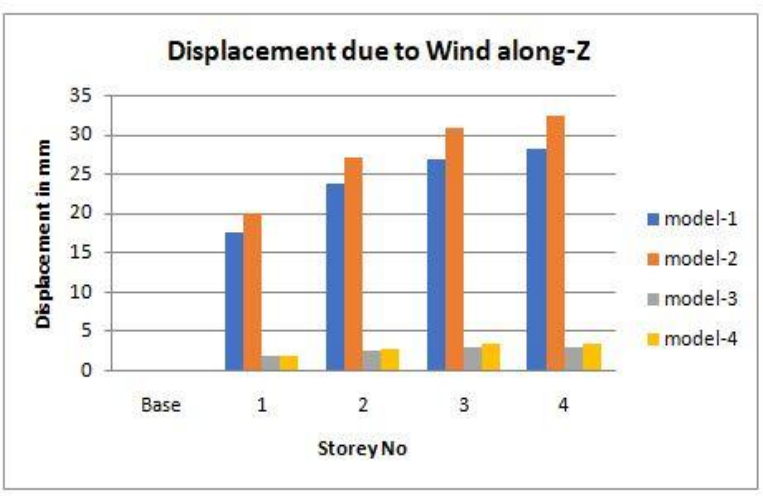

Fig 5.12: Storey displacement in $\mathrm{mm}$ for various models along Z-direction due to Wind, all models are Channel with lip

From the Fig 5.12 it is observed that the storey displacement for model 1 is $28.05 \mathrm{~mm}$ along Z-direction. When we add bracing in $\mathrm{X}$-direction the storey displacement is increases by $13.26 \%$ in model 2 , when we add bracing in Z-direction the storey displacement is decreases by $89.59 \%$ in model 3 , when we add bracing in $\mathrm{X}$ and $\mathrm{Z}$ direction the storey displacement is decreases by $87.77 \%$ in model 4 compared to model 1

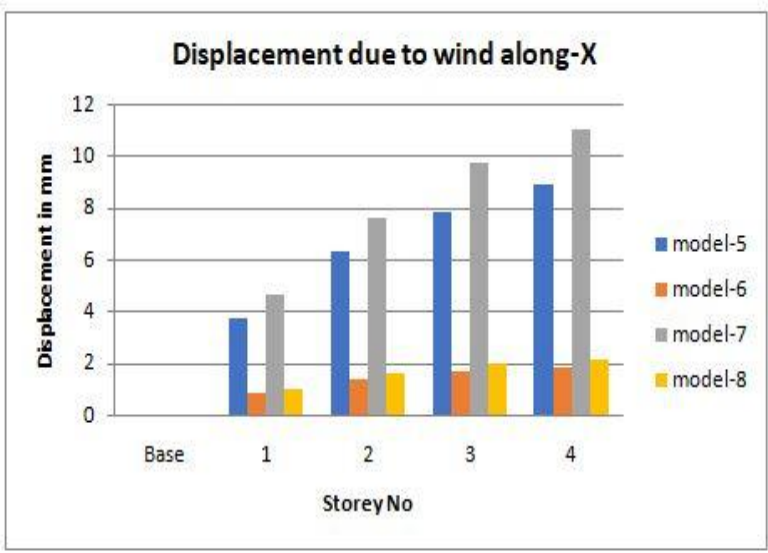

Fig 5.13: Storey displacement in $\mathrm{mm}$ for various models along $\mathrm{X}$-direction due to Wind, all models are Zee with lip

From the Fig 5.13 it is observed that the storey displacement for model 5 is $8.87 \mathrm{~mm}$ along $\mathbf{X}$-direction. When we add bracing in X-direction the storey displacement is decreases by $79.59 \%$ in model 6 , when we add bracing in Z-direction the storey displacement is increases by $19.50 \%$ in model 7 , when we add bracing in $\mathrm{X}$ and $\mathrm{Z}$ direction the storey displacement is decreases by $75.64 \%$ in model 8, compared to model 5.

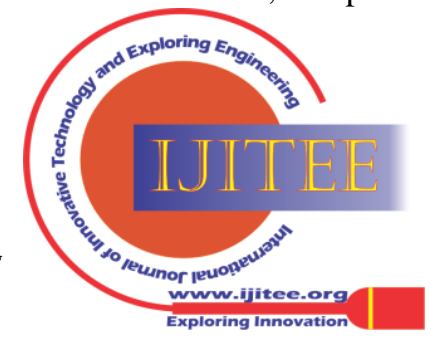




\section{Analysis of Retrofitted Cold Formed Steel Multistory Building Frame}

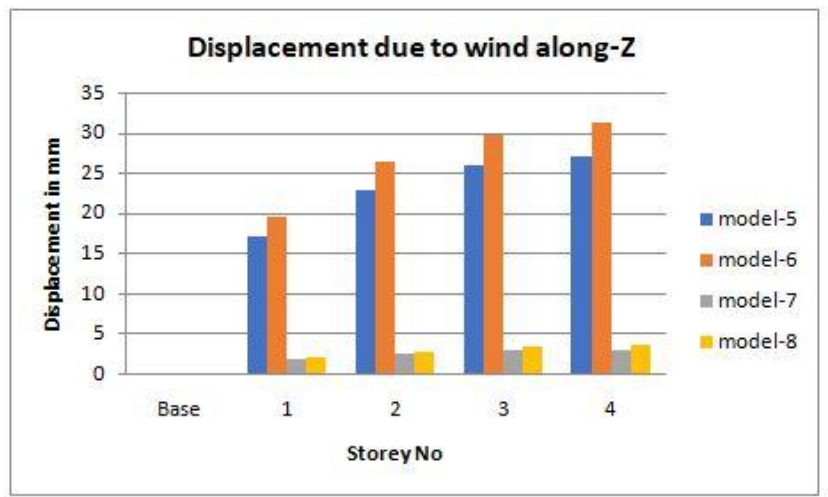

Fig 5.14: Storey displacement in $\mathrm{mm}$ for various models along Z-direction due to Wind, all models are Zee with lip

From the Fig 5.14 it is observed that the storey displacement for model 5 is $27.06 \mathrm{~mm}$ along Z Z-direction. When we add bracing in $\mathrm{X}$-direction the storey displacement is increases by $13.32 \%$ in model 6 , when we add bracing in Z-direction the storey displacement is decreases by $89.04 \%$ in model 7 , when we add bracing in $\mathrm{X}$ and $\mathrm{Z}$ direction the storey displacement is decreases by $87.34 \%$ in model 8 , compared to model 5.

Story drift: Storey drift values are graphically represented in Fig 5.15, Fig 5.16. Fig 5.17 and Fig 5.18.

Fig 5.15: Drift value for various models along $X$-direction due to Wind, all models are Channel with lip

From the Fig 5.15 it is observed that the storey drift for model 1 is $9.48 \mathrm{~mm}$ along $\mathbf{X}$-direction. When we add bracing in $\mathrm{X}$-direction the storey drift is decreases by $81.11 \%$ in model 2 , when we add bracing in Z-direction the storey drift is increases by $19.38 \%$ in model 3, when we add bracing in $\mathrm{X}$ and $\mathrm{Z}$ direction the storey drift is decreases by $76.89 \%$ in model 4, compared to model 1.

Fig 5.16: Drift value for various models along $\mathrm{Z}$-direction due to Wind, all models is Channel with lip
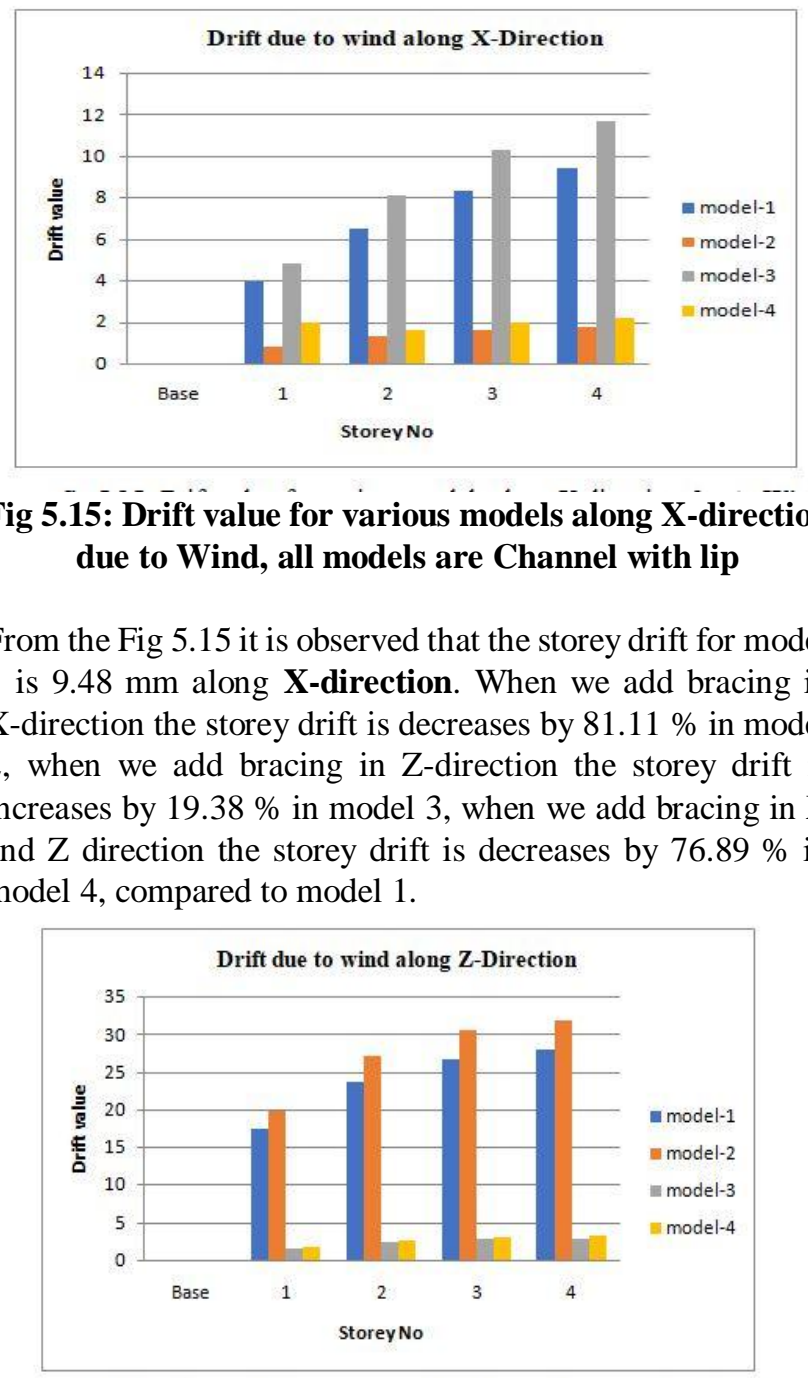

From the Fig 5.16 it is observed that the storey drift for model 1 is $28.06 \mathrm{~mm}$ along Z-direction. When we add bracing in $\mathrm{X}$-direction the storey drift is increases by $12.42 \%$ in model 2 , when we add bracing in Z-direction the storey drift is decreases by $89.87 \%$ in model 3 , when we add bracing in $X$ and $\mathrm{Z}$ direction the storey drift is decreases by $88.27 \%$ in model 4, compared to model 1.

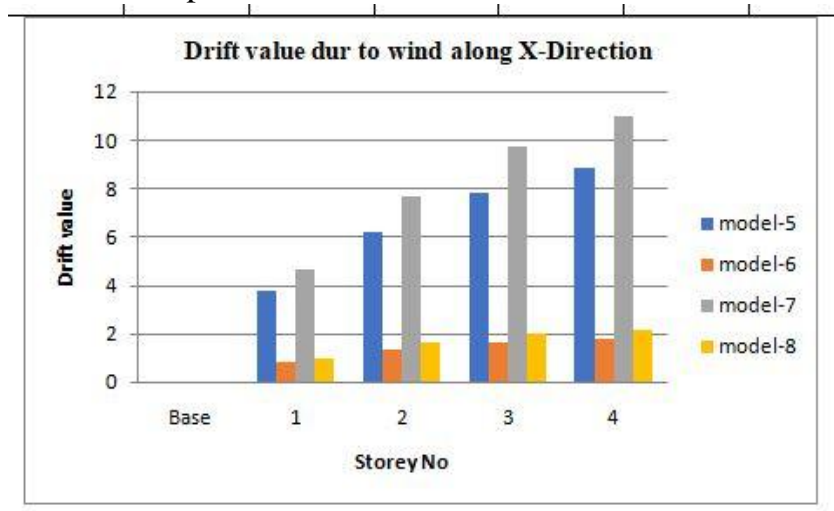

Fig 5.17: Drift value for various models along $\mathrm{X}$-direction due to Wind, all models is Zee with li

From the Fig 5.17 it is observed that the storey drift for model 5 is $8.91 \mathrm{~mm}$ along $\mathbf{X}$-direction. When we add bracing in $\mathrm{X}$-direction the storey drift is decreases by $79.91 \%$ in model 6 , when we add bracing in Z-direction the storey drift is increases by $19.29 \%$ in model 7 , when we add bracing in $X$ and $\mathrm{Z}$ direction the storey drift is decreases by $75.53 \%$ in model 8, compared to model 5.

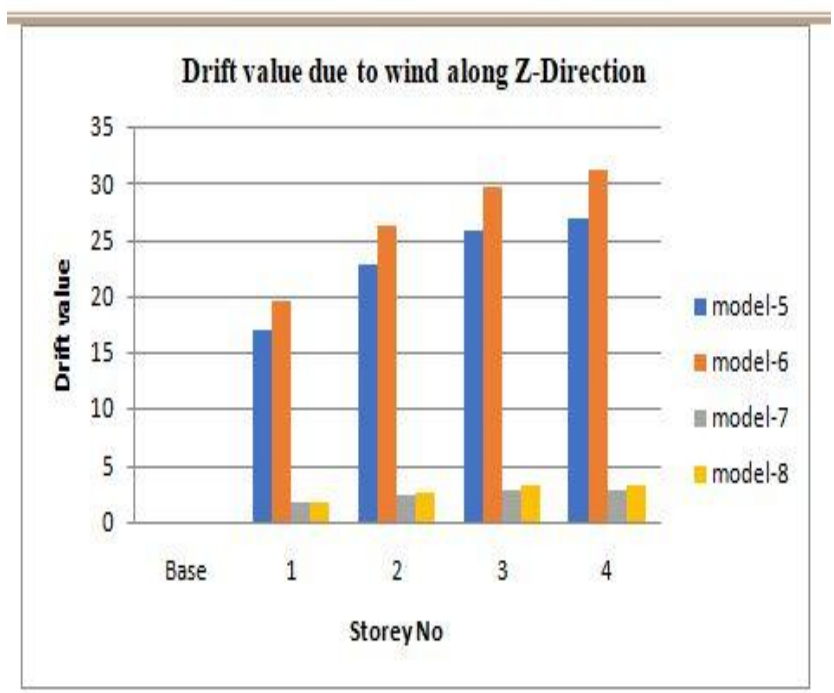

Fig 5.18: Drift value for various models along Z-direction due to Wind, all models are Zee with lip

From the Fig 5.18 it is observed that the storey drift for model 5 is $27.07 \mathrm{~mm}$ along Z-direction. When we add bracing in $\mathrm{X}$-direction the storey drift is increases by $13.32 \%$ in model 6 , when we add bracing in Z-direction the storey drift is decreases by $89.36 \%$ in model 7 , when we add bracing in $X$ and $\mathrm{Z}$ direction the storey drift is decreases by $87.73 \%$ in model 8, compared to model 5.

Published By:

Blue Eyes Intelligence Engineering

Retrieval Number: 100.1/ijitee.K946809101121 


\section{COMPARATIVE STUDY OF RESULTS OF WIND AND SEISMIC ANALYSIS:}

\section{A .Storey displacement:}

In X-direction: The values of storey displacement in X-direction for both wind and seismic are graphically represented in Fig 5.19 \& Fig 5.20.

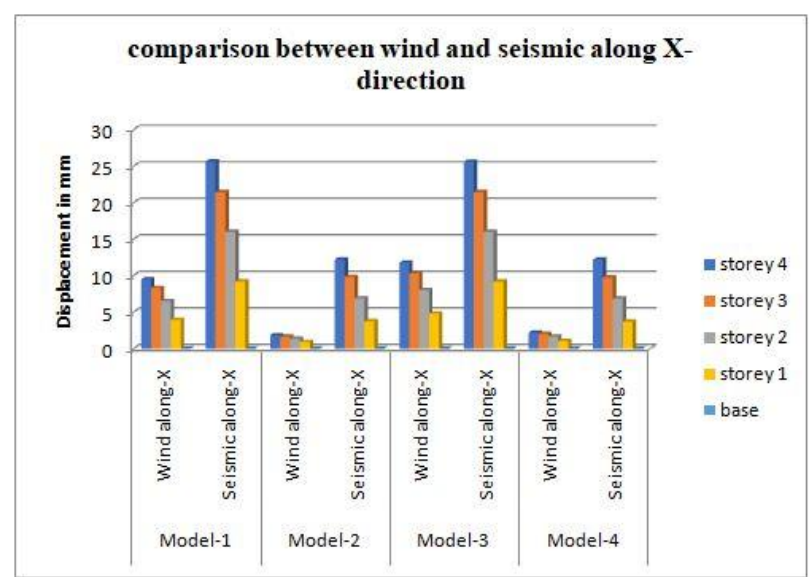

Fig 5.19: Storey displacement values for various models along $\mathrm{X}$-Direction due to wind and seismic analysis.

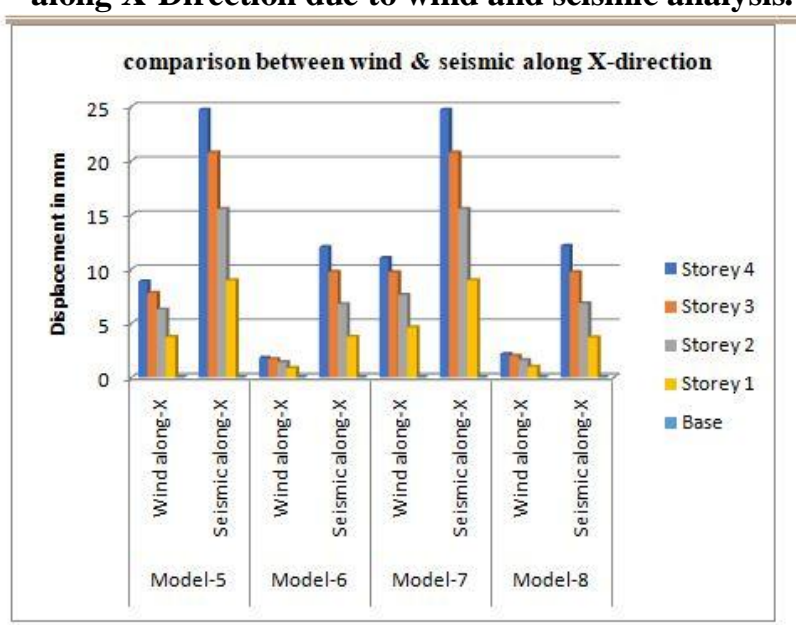

Fig 5.20: Storey displacement values for various models along $\mathrm{X}$-Direction due to wind and seismic analysis.

From the Fig 5.19 it is observed the storey displacement for model 1 due to wind load is $9.49 \mathrm{~mm}$, whereas due to seismic load the storey displacement is increases by $62.94 \%$, for model 2 the storey displacement due to wind load is $1.82 \mathrm{~mm}$, where as the storey displacement due to seismic load is increases by $85.09 \%$, for model 3 the storey displacement due to wind load is $11.78 \mathrm{~mm}$, where as the storey displacement due to seismic load is increases by $53.95 \%$, for model 4 the storey displacement due to wind load is $2.19 \mathrm{~mm}$, where as the storey displacement due to seismic load is increases by $82.05 \%$.

From the Fig 5.20 it is observed the storey displacement for model 5 due to wind load is $8.87 \mathrm{~mm}$, whereas due to seismic load the storey displacement is increases by $64.06 \%$, for model 6 the storey displacement due to wind load is $1.81 \mathrm{~mm}$, where as the storey displacement due to seismic load is increases by $84.93 \%$, for model 7 the storey displacement due to wind load is $11.02 \mathrm{~mm}$, where as the storey displacement due to seismic load is increases by $55.36 \%$, for model 8 the storey displacement due to wind load is $2.16 \mathrm{~mm}$, where as the storey displacement due to seismic load is increases by $82.19 \%$.

In Z-direction: The values of storey displacement in Z-direction for both wind and seismic are graphically represented in Fig 5.21 \& Fig 5.22.

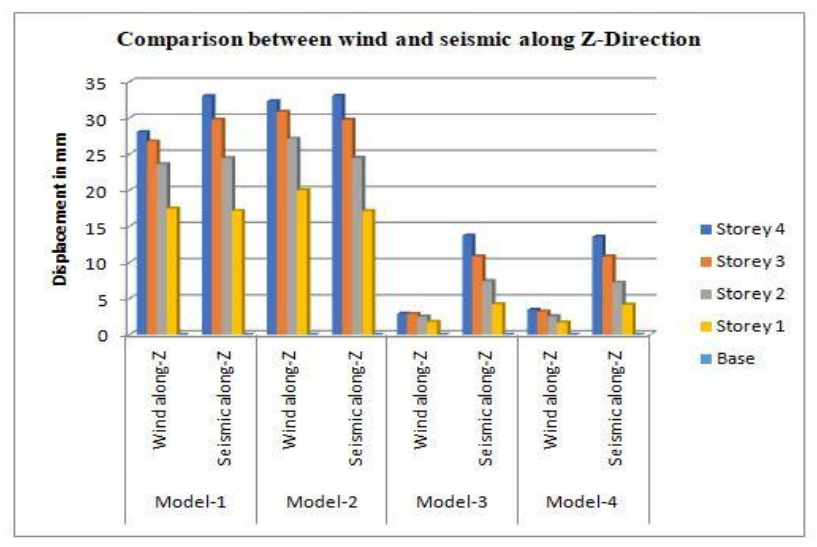

Fig 5.21: Storey displacement values for various models along Z-Direction due to wind and seismic analysis.

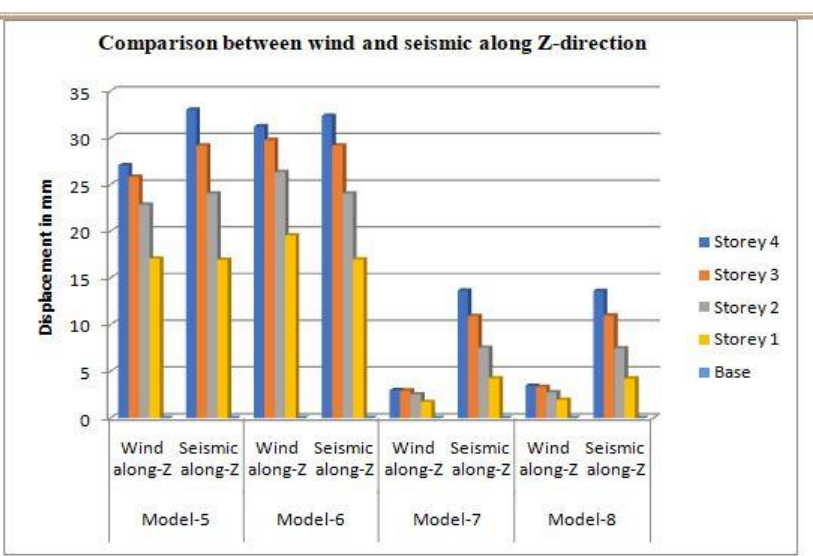

Fig 5.22: Storey displacement values for various models along Z-Direction due to wind and seismic analysis.

From the Fig 5.21 it is observed the storey displacement for model 1 due to wind load is $28.05 \mathrm{~mm}$, whereas due to seismic load the storey displacement is increases by $15.02 \%$, for model 2 the storey displacement due to wind load is 32.34 $\mathrm{mm}$, where as the storey displacement due to seismic load is increases by $2.23 \%$, for model 3 the storey displacement due to wind load is $2.92 \mathrm{~mm}$, where as the storey displacement due to seismic load is increases by $78.68 \%$, for model 4 the storey displacement due to wind load is $3.43 \mathrm{~mm}$, where as the storey displacement due to seismic load is increases by $74.72 \%$. From the Fig 5.22 it is observed the storey displacement for model 1 due to wind load is $27.06 \mathrm{~mm}$, whereas due to seismic load the storey displacement is increases by $17.97 \%$, for model 2 the storey displacement due to wind load is $31.22 \mathrm{~mm}$, where as the storey displacement due to seismic load is increases by $3.46 \%$, for model 3 the storey displacement due to wind load is $2.99 \mathrm{~mm}$, where as the storey displacement due to seismic load is increases by $78.06 \%$, for model 4 the storey displacement due to wind load is $3.45 \mathrm{~mm}$, where as the storey displacement due to seismic load increases by $74.65 \%$.

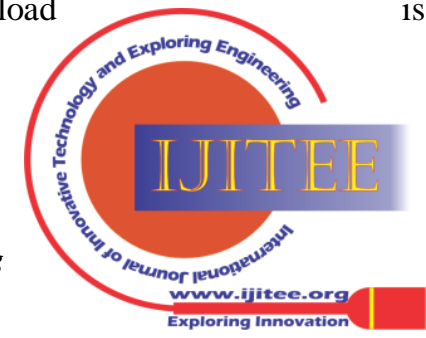




\section{Analysis of Retrofitted Cold Formed Steel Multistory Building Frame}

\section{B .Storey drift:}

In X-direction: The values of storey drift in X-direction for both wind and seismic are graphically represented in Fig 5.23 \& Fig 5.24

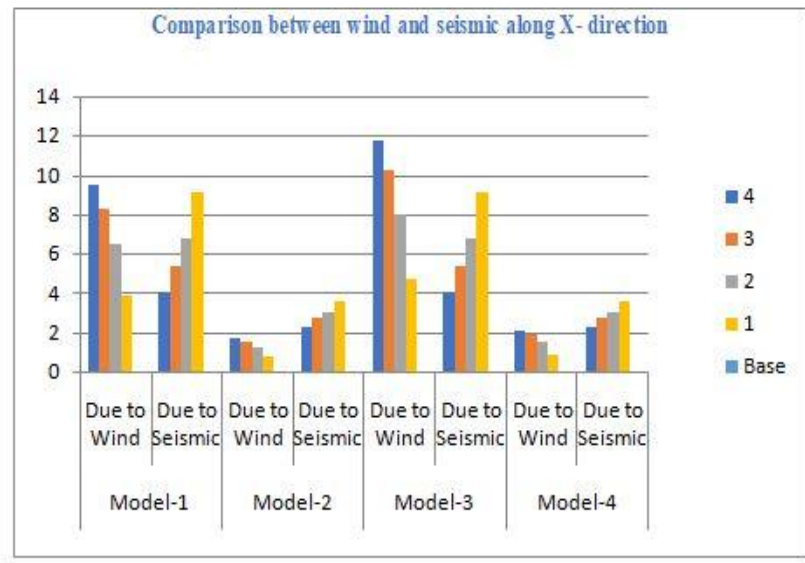

Fig 5.23: Storey drift values for various models along $X$-Direction due to wind and seismic analysis

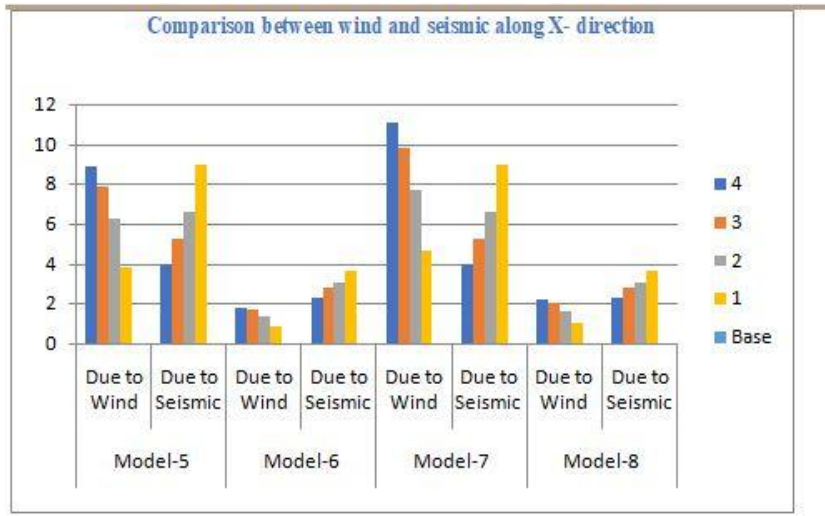

Fig 5.24: Storey drift values for various models along $\mathrm{X}$-Direction due to wind and seismic analysis

From the Fig 5.23 it is observed the storey drift for model 1 due to wind load is $9.48 \mathrm{~mm}$, whereas due to seismic load the storey drift is decreased by $56.22 \%$, for model 2 the storey drift due to wind load is $1.79 \mathrm{~mm}$, where as the storey drift due to seismic load is increases by $22.84 \%$, for model 3 the storey drift due to wind load is $11.78 \mathrm{~mm}$, where as the storey drift due to seismic load is decreased by $64.77 \%$, for model 4 the storey drift due to wind load is $2.19 \mathrm{~mm}$, where as the storey drift due to seismic load is increases by $5.60 \%$. From the Fig 5.24 it is observed the storey drift for model 5 due to wind load is $8.91 \mathrm{~mm}$, whereas due to seismic load the storey displacement is decreased by $55.89 \%$, for model 6 the storey drift due to wind load is $1.79 \mathrm{~mm}$, whereas the storey drift due to seismic load is increases by $21.83 \%$, for model 7 the storey displacement due to wind load is $11.04 \mathrm{~mm}$, whereas the storey drift due to seismic load is decreased by $64.40 \%$, for model 8 the storey drift due to wind load is 2.16 $\mathrm{mm}$, whereas the storey drift due to seismic load is increases by $4.80 \%$.

In Z-direction: The values of storey drift in Z-direction for both wind and seismic are graphically represented in Fig 5.25 \& Fig 5.26 .

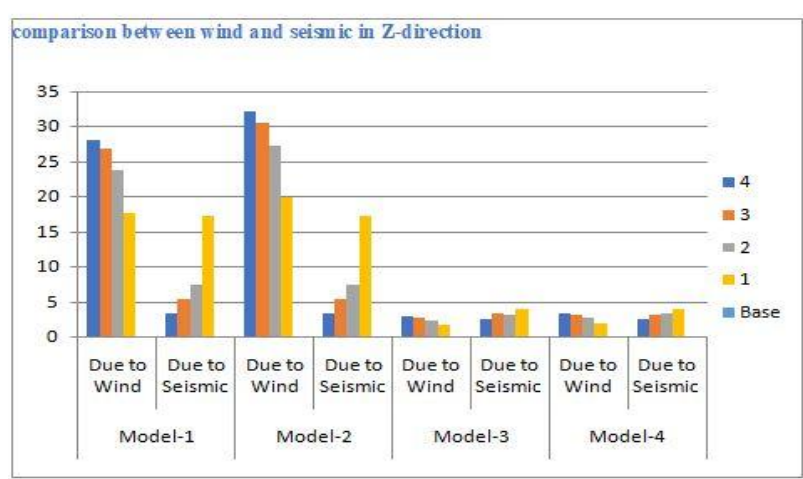

Fig 5.25: Storey drift values for various models along Z-Direction due to wind and seismic analysis

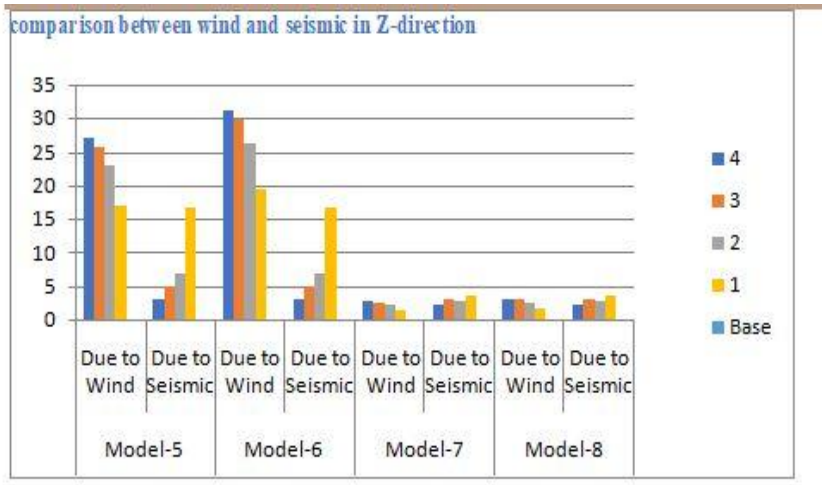

Fig 5.26: Storey drift values for various models along

Z-Direction due to wind and seismic analysis

From the Fig 5.25 it is observed the storey drift for model 1 due to wind load is $28.06 \mathrm{~mm}$, whereas due to seismic load the storey drift is decreased by $88.21 \%$, for model 2 the storey drift due to wind load is $32.04 \mathrm{~mm}$, where as the storey drift due to seismic load is decreased by $89.70 \%$, for model 3 the storey drift due to wind load is $2.84 \mathrm{~mm}$, where as the storey drift due to seismic load is decreased by $13.03 \%$, for model 4 the storey drift due to wind load is $3.29 \mathrm{~mm}$, where as the storey drift due to seismic load is decreased by $24.92 \%$

From the Fig 5.26 it is observed the storey drift for model 5 due to wind load is $27.07 \mathrm{~mm}$, whereas due to seismic load the storey drift is decreased by $88.21 \%$, for model 6 the storey drift due to wind load is $31.23 \mathrm{~mm}$, where as the storey drift due to seismic load is decreased by $89.81 \%$, for model 7 the storey drift due to wind load is $2.88 \mathrm{~mm}$, where as the storey drift due to seismic load is decreased by $14.58 \%$, for model 8 the storey drift due to wind load is $3.32 \mathrm{~mm}$, where as the storey drift due to seismic load is decreased by $25.90 \%$.

\section{CONCLUSION AND SCOPE FOR FURTHER STUDY}

A . Conclusions: Following conclusion are drawn from the results of analysis.

1. The time period for seismic load decreased by $69.3 \%$ and $30.2 \%$ when bracing is provided in $\mathrm{X} \mathrm{\&} \mathrm{Z}$ direction respectively for frame with light gauge channel section as beam elements when compared to time period of frame without bracing.

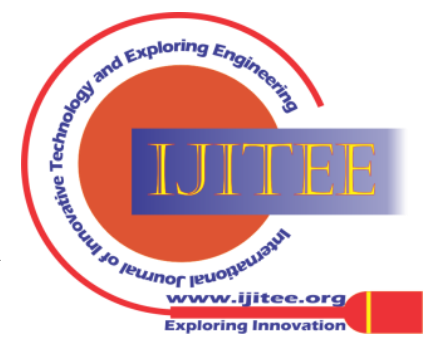


The time period decreased by $69.4 \%$ when bracing is provided in both X\&Z direction.

2. When bracing was provided in $\mathrm{X} \& \mathrm{Z}$ direction independently the storey displacement due to seismic load is decreased by $52.3 \%$ and $58.4 \%$ in the respective direction alone when compared to bare frame.

The storey displacement decreased by $52.4 \%$ in X-direction \& 58.9\%in Z-direction when bracing is provided in both $\mathrm{X}$ \& $\mathrm{Z}$ direction.

3. The storey drift due to seismic load decreased by $44.1 \%$ when bracing is provided both in $\mathrm{X} \& \mathrm{Z}$ direction as compared to frame without bracing. The behaviour for storey drift was identical to that of storey displacement when bracing is provided only in X\&Z direction.

4. The base shear due to seismic load increased by $56.2 \%$ when bracing is provided in both direction due to increase in the seismic weight.

5. The behaviour of braced frame with light gauge Zee section beams was identical to that of corresponding frame with Light gauge channel section beams.

6. The storey displacement values due to wind load is lower than that due to seismic load, whereas the storey drift values are higher in case of wind load for all the models when compared to seismic loads.

7. The effect of bracing in both directions was beneficial in case of wind loading also reducing the storey displacement and storey drift values to identical level of the behaviour under seismic loading.

8. The bracing in both directions for frame with light gauge channel section beams and also for frame with light gauge Zee sectionbeams proved equally beneficial in increasing the ductility and stiffness of the frame.

B . Scope of further study

1. The current work can be extended for higher number of stories and irregular conFiguration.

2. The present work is carried out for seismic load in Zone III, further work can be carried out for different Zones.

3. The present work is carried out for rectangular building; further work can be carried out for irregular building.

4. The present work is carried out by considering beam section as channel with lip and Zee with lip further work can be carried out by taking different cold formed sections.

5. Studies on other forms of retrofitting can be carried out.

\section{REFERENCES}

1. Giuseppe Oliveto And Massimo Marletta (2005): Seismic retrofitting of for RC and steel buildings using traditional and innovative techniques ISET journal of earthquake technology, 42, 21-26

2. S. Vigneshkannan, J.Abdul Bar, P.Easwaran: A General Study of Light Gauge Steel Structures - A Review International Journal of Advanced Research Methodology in Engineering \& Technology, ISSN 2456-6446 Volume 1, Issue 4, December 2017

3. Ravindra B. Kulkarni Zuarker Rajesh Shripad: Experimental Investigation on Cold Formed Light Gauge Rectangular Hollow Section with Welded knee Joints. IJSRD - International Journal for Scientific Research \& Development| Vol. 4, Issue 2016 | ISSN (online): 2321-0613

4. Weiming Yan, Tingting Mu, Zhiqiang Xie and Cheng Yu (2019): Experimental investigation of typical connections for fabricated cold-formed steel structures Advances in Structural Engineering2019, Vol. 22(1) 141-155

5. IS 1893 (part-1) 2002 IS criteria for earthquake resistant design of structures part 1: general provisions and building ( $5^{\text {th }}$ revision).

\section{Authors Profile}

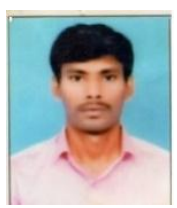

Udayakumar PG Student, Department of Civil Engineering, PDA College of Engineering Kalaburgi-585102, Karnataka, India Email: udayakumarpatil123@gmail.com

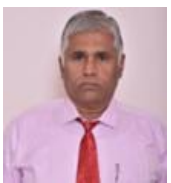

Dr. Aravindkumar B Harwalkar, Associate Professor Department of Civil Engineering, PDA College of Engineering, Kalaburgi -585102, Karnataka, India. Email: harwalkar_ab@yahoo.co.in

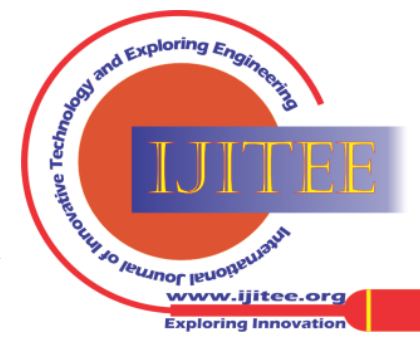

